\title{
LEARNING TO LIVE WITH LESS WATER
}

CLIMATE CHANGE AND A GROWING POPULATION ARE PUTTING PRESSURE ON OUR GLOBAL WATER RESOURCES, ESPECIALLY THOSE USED FOR AGRICULTURE. HOW CAN WE RESPOND TO THIS CHALLENGE AND ENSURE THAT FARMERS HAVE THE WATER THEY NEED? DR EMILE ELIAS AND THE USDA SOUTHWEST CLIMATE HUB ARE WORKING HARD TO ANSWER THIS QUESTION.

\section{IMAGINE THIS SCENARIO}

Bella is 16 and lives on a farm. Sadly, there has been little rainfall in recent times, which means the region she lives in is in the grips of severe drought. Water sources are drying up, and without this water, farmers are unable to care for their crops. Production is at an all-time low, and it looks like Bella's parents may have to give up their farm, which has been in the family for many generations. Not only that, the farm is their livelihood, and Bella is worried about the future for her and her family.

According to the World Health Organisation (WHO), half of the world's population will be living in water-stressed areas by 2025. Many will simply not have the water needed to tend to their crops and livestock, among other things. Food production will be affected, and so will the livelihoods of thousands of people.

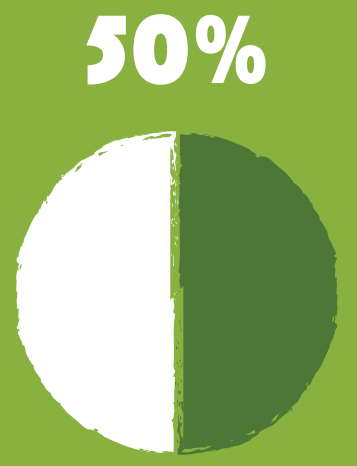

of the world's population will be living in water-stressed areas by 2025
Climate change, and increases in the frequency, severity and duration of agricultural drought, have contributed to a shortage of water for agricultural use. In some parts of the world, poor land management practices and water wastage have put further strain on water supplies. Clearly, something needs to be done to ensure that our water resources are properly managed, especially in light of a rapidly changing climate and a growing global population.

Dr Emile Elias and her colleagues at the USDA Southwest Climate Hub hope that the knowledge gained through their research will ensure that our water resources are well managed and protected, and that ultimately, farmers have enough water to support their livelihoods. Emile's area of focus is America's southwest - especially the upper Rio Grande basin in southern Colorado and northern New Mexico.

\section{WHAT IS IT LIKE IN THE}

SOUTHWESTERN REGION OF THE US? The southwest is one of the hottest and driest areas of the US. There is often very little rain. In fact, much of the area's water comes from snowmelt runoff from mountains during the spring. So, water can be in short supply.

Sometimes the area reaches a tipping point. "During the exceptional drought of 2018, for example, some communities ran completely out of water," says Emile. "Many had to haul water long distances and this negatively impacted agriculture in the region." Some farmers simply did not have the resources to support their livestock.
WHY IS THE WATER SCARCITY

PROBLEM GETTING WORSE?

"Drought is a way of life in the region," says Emile. However, it appears that in recent times, things are different, with temperature-related agricultural droughts now intensifying.

Emile believes that the increasing frequency and severity of agricultural droughts are due, in part, to climate change, and Climate Hub's investigations into the amount of water held in snow in the San Juan and Sangre de Cristo mountains, and runoff (water produced from melting snow) into the Rio Grande river, are indicating that the situation is likely to get worse. "Warming temperatures are leading to lower amounts of water held in the snow, reduced soil moisture, and changes in runoff timing," she says.

WHAT HAVE HYDROLOGICAL MODELS SHOWN?

Emile and her colleagues used hydrologic simulation models in their studies (hydrology refers to the study of water and its

distribution on Earth). A model is a simplified version of reality that allows for observation and testing. "In hydrologic modelling we use mathematics to represent reality. Simulation models are built from mathematical principles and generally use computing technology to test different scenarios," Emile explains.

To get a full picture of possible outcomes, the team modelled four potential climate scenarios over the next 80 years or so. The scenarios were as follows: 1) warm and wet; 
